\title{
Pengaruh posisi pintu masuk (entrance) bubu apung terhadap hasil tangkapan pada rumpon laut dangkal
}

\author{
The effect of entrance position of floating trap on fish catch in shallow water raft \\ JENDRA ROMPIS* ${ }^{*}$ ISROJATY J. PARANSA dan REVOLS D. CH. PAMIKIRAN \\ Program Studi Pemanfaatan Sumberdaya Perikanan, Fakultas Perikanan Dan Ilmu Kelautan, \\ Universitas Sam Ratulangi, Manado 96115
}

\begin{abstract}
Manado Bay is one of North Sulawesi Utara waters that holds pelagic fish resources as major commodity. Fishermen take advantages of raft as an attractor to gather pelagic fishes and then catch them using floating rafts. This study aimed to study the fishing success of floating trap under the raft, the effect of entrance position, and identify the fish species. It was carried out using an experimental method by operating two units of floating traps, each of which used 2 entrance positions, one on the rear and front and the other on the left and right. Both gears were set in a composed state and hung under the raft. In seven trips of fishing operations, there were 702 individuals caught, 407 in the trap with rear and front entrance and 295 individuals in that with left and right entrance. As conclusion, the entrance construction and fish behavior affected the fishing success of the floating trap.
\end{abstract}

Keywords: FADs, entrance, floating trap, pelagic fish

\begin{abstract}
ABSTRAK
Perairan Teluk Manado merupakan salah satu kawasan perairan di Sulawesi Utara yang memiliki sumber daya ikan pelagis yang merupakan komoditas utama. Nelayan menggunakan rumpon sebagai atraktor untuk mengumpul ikan pelagis, yang kemudian akan ditangkap menggunakan alat tangkap seperti bubu apung. Adapun tujuan penelitian ini yaitu untuk mempelajari keberhasilan hasil tangkapan bubu apung di bawah rumpon, mempelajari pengaruh posisi pintu masuk (entrance) bubu apung terhadap hasil tangkapan ikan dan mengidentifikasi hasil tangkapan ikan dengan bubu apung. Penelitian ini dilakukan dengan mengikuti metode eksperimental. Pengumpulan data dilakukan dengan cara mengoperasikan 2 unit alat tangkap bubu apung. Di setiap bubu apung mempunyai 2 posisi pintu yaitu bubu pertama pintu depan dan pintu belakang, bubu kedua pintu samping kanan dan pintu samping kiri. Kemudian posisi kedua alat tangkap dalam keadaan tersusun yang kemudian dioperasikan dengan posisi tergantung di bawah rumpon pada perairan Teluk Manado. Jumlah ikan hasil tangkapan selama 7 trip operasi adalah sebanyak 702 ekor, pada bubu pintu depan dan pintu belakang berjumlah 407, bubu pintu samping kanan dan pintu samping kiri berjumlah 295. Kesimpulan dari penelitian ini adalah keberhasilan tangkapan ikan dengan bubu apung dipengaruhi oleh konstruksi pintu masuk (entrance) bubu dan tingkah laku ikan pelagis.
\end{abstract}

Kata-kata kunci: rumpon, pintu masuk, bubu apung, ikan pelagis

\section{PENDAHULUAN}

Indonesia adalah negara maritim dengan luas total wilayah adalah 7,81 juta $\mathrm{km}^{2}$ yang terdiri dari 2,01 juta $\mathrm{km}^{2}$ daratan, 3,25 juta $\mathrm{km}^{2}$ lautan, dan 2,55 juta $\mathrm{km}^{2}$ Zona Ekonomi Eksklusif (ZEE) (KKP, 2017). Berdasarkan luas wilayah perairan ini, Indonesia memiliki sumber daya hayati yang meliputi ikan, terumbu karang, padang lamun, mangrove dan biota laut lain (PERMEN KP, 2016).

Masyarakat nelayan yang ada di daerah Teluk Manado memanfaatkan potensi sumber daya ikan ini melalui usaha penangkapan ikan dengan menggunakan peralatan yang relatif sederhana dan menggunakan alat bantu rumpon (Mandagi $d k k$, 2016).

\footnotetext{
*Penulis untuk penyuratan; e-mail: Jendrarompis3@gmail.com
} 
Nelayan menggunakan rumpon sebagai atraktor untuk mengumpul ikan pelagis, yang kemudian akan ditangkap menggunakan alat tangkap pancing ulur atau noru, soma darape (Dimara $d k k, 2015$ ). Di lain pihak, penangkapan ikan pelagis dapat dilakukan dengan alat tangkap bubu apung yang merupakan alat tangkap pasif, penangkapan ini dapat dilakukan di perairan pesisir pantai.

Untuk itu, perlu dilakukan penenelitian tentang alat tangkap bubu apung ini sebagai salah satu alternatif untuk menangkap ikan pelagis yang memberi peluang terhadap hasil tangkapan dalam jumlah yang banyak

\section{METODE PENELITIAN}

Penelitian ini dilakukan dengan mengikuti metode eksperimental dan dianalisa data tangkapan menggunakan model analisis komparatif dua sampel tidak berpasangan atau bebas (Hasan, 2004).

Penelitian dilaksanakan di Perairan Teluk Manado. Pengumpulan data dilakukan dengan cara mengoperasikan 2 unit alat tangkap bubu apung. Di setiap bubu apung mempunyai 2 posisi pintu yaitu bubu pertama pintu depan dan pintu belakang, bubu kedua pintu samping kanan dan pintu samping kiri.

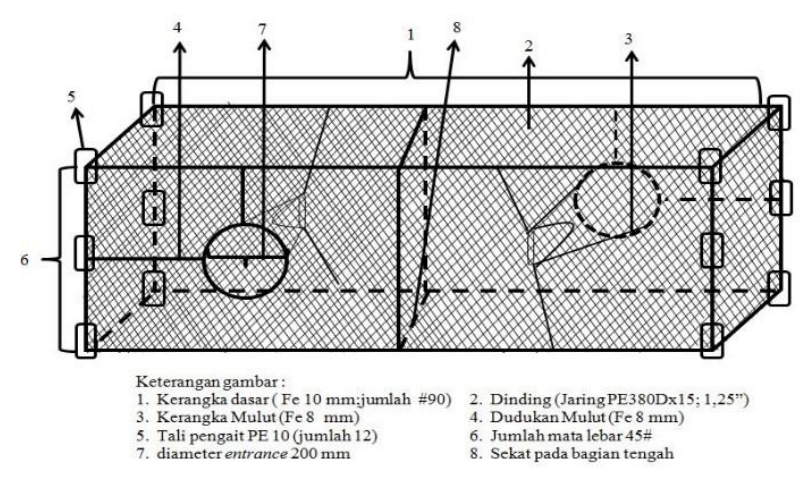

Gambar 1. Desain alat tangkap bubu apung (depan/belakang) ukuran $2 \times 1 \mathrm{~m}$

\section{HASIL DAN PEMBAHASAN}

\section{Hasil Tangkapan Ikan}

Jumlah ikan hasil tangkapan selama 7 trip operasi adalah sebanyak 702 ekor dan jumlah ini bervariasi menurut tipe bubu (Tabel 2). Pada bubu tipe 1 (pintu depan dan belakang) lebih banyak ikan yang tertangkap (407 ekor) dari pada bubu tipe 2 (pintu samping kanan dan kiri) yakni sebanyak 295 ekor (Tabel 2).
Bubu yang digunakan terbuat dari kerangka dasar besi beton berdiameter $10 \mathrm{~mm}$, yang dimana berbentuk persegi panjang dengan dimensi $2 \times 1 \times 1$ $\mathrm{m}$, memakai sekat pada posisi tengah sehingga menjadi 2 bagian dengan dimensi 1x1x1m. Setiap dinding-dinding bubu terbuat material jaring PE 380Dx15 dengan besar mata 1,25 inci, jumlah mata arah panjang 90 dan jumlah mata arah lebar 45 dan disetiap dinding-dinding bubu dilapisi dengan daun kelapa (Cocos rucifera).

Pintu masuk (entrance) bubu beserta dudukannya terbuat dari kerangka besi beton dengan diameter $8 \mathrm{~cm}$, berbentuk kerucut ke arah dalam berdiameter $200 \mathrm{~mm}$. Dinding pada Pintu masuk (entrance) bubu terbuat dari material jaring PE 380Dx 15 dengan besar mata 1,25 inci.

Posisi kedua alat tangkap dalam keadaan tersusun yang kemudian dioperasikan dengan posisi tergantung di bawah rumpon pada perairan Teluk Manado. Proses kegiatan operasi penangkapan ikan terdiri dari beberapa tahap yaitu persiapan operasi penangkapan ikan, penurunan alat tangkap ikan (Setting) dan penarikan alat tangkap (Hauling). Desain kedua unit alat tangkap bubu apung dapat dilihat pada gambar 1 dan gambar 2 .

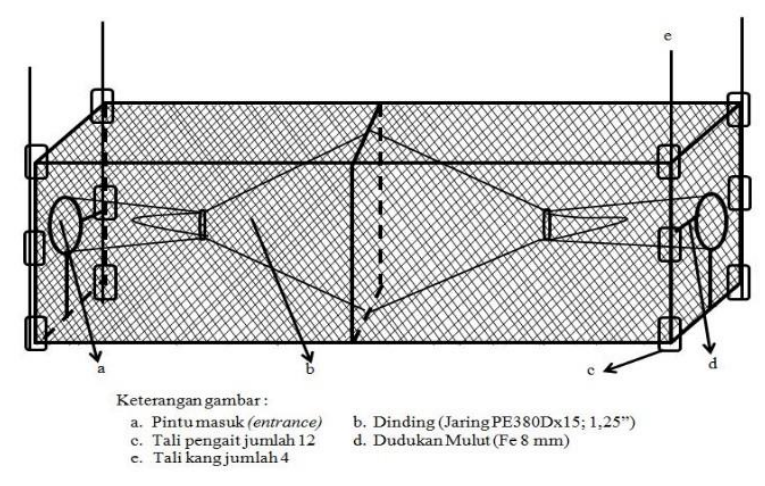

Gambar 2. Desain alat tangkap bubu apung (samping kanan/kiri) ukuran $2 \times 1 \mathrm{~m}$

Ikan-ikan yang tertangkap dengan bubu apung paling banyak adalah ikan Decapterus sp. dan ikan Selaroides $s p$. yang merupakan ikan target tangkap terutama pada trip 6 dan 7. Terdapat juga ikan karang yang tertangkap yaitu Sergeant major dan Scribled leatherjacket terutama pada trip 1 sampai 5. Ikan yang paling sedikit tertangkap adalah ikan Scribled leatherjacket yang hanya berjumlah 2 ekor tertangkap pada trip pertama. 
Tabel 1. Jumlah hasil tangkapan (ekor) menurut tipe bubu

\begin{tabular}{|c|c|c|c|c|c|c|}
\hline \multirow{3}{*}{$\begin{array}{l}\text { Trip Operasi } \\
\text { Penangkapan }\end{array}$} & \multicolumn{6}{|c|}{ Jumlah Hasil Tangkapan (ekor) } \\
\hline & \multicolumn{3}{|c|}{ Tipe bubu 1} & \multicolumn{3}{|c|}{ Tipe bubu 2} \\
\hline & Depan & Belakang & $\Sigma$ & Samping Kanan & Samping Kiri & $\Sigma$ \\
\hline 1 & 6 & 2 & 8 & 3 & 6 & 9 \\
\hline 2 & 3 & 2 & 5 & 3 & 1 & 4 \\
\hline 3 & 3 & 1 & 4 & 2 & 3 & 5 \\
\hline 4 & 7 & 3 & 10 & 1 & 3 & 4 \\
\hline 5 & 20 & 2 & 22 & 2 & 2 & 4 \\
\hline 6 & 56 & 33 & 89 & 46 & 33 & 79 \\
\hline 7 & 168 & 101 & 269 & 92 & 98 & 190 \\
\hline Jumlah & 263 & 144 & 407 & 149 & 146 & 295 \\
\hline
\end{tabular}

Tabel 2. Jumlah (ekor) dan jenis ikan tangkapan bubu apung pada setiap trip operasi

\begin{tabular}{|c|c|c|c|c|c|c|c|c|c|}
\hline \multirow[t]{2}{*}{ Nama Lokal } & \multirow{2}{*}{$\begin{array}{l}\text { Nama Ilmiah (Allen } \\
\text { G, 2000) }\end{array}$} & \multicolumn{7}{|c|}{ Trip Operasi } & \multirow{2}{*}{$\begin{array}{l}\text { Jumlah } \\
\text { (ekor) }\end{array}$} \\
\hline & & 1 & 2 & 3 & 4 & 5 & 6 & 7 & \\
\hline $\begin{array}{l}\text { Lahaminang/ } \\
\text { strep-strep }\end{array}$ & Abudefdaf vaigiensis & 14 & 9 & 7 & 14 & 26 & - & - & 70 \\
\hline $\begin{array}{l}\text { Sunga } \\
\text { batang/deto }\end{array}$ & Aluterus scriptus & 2 & - & - & - & - & - & - & 2 \\
\hline Malalugis & Decapterus sp. & 1 & - & 2 & - & - & 104 & 271 & 378 \\
\hline Tude & Selaroides sp. & - & - & - & - & - & 64 & 188 & 252 \\
\hline
\end{tabular}

\section{Hasil Analasis Data Perlakuan}

Untuk kepentingan analisis uji $\mathrm{t}$ ind terhadap hasil tangkapan pada bubu apung, maka data dalam tabel 2 disederhanakan dan diolah dengan hasil yang diuraikan pada tabel 3. Hasil analisis jumlah tangkapan (Tabel 3) yang diuji menunjukkan bahwa $\mathrm{t}$ hitung $=0,4172<\mathrm{t}$ Tabel $\mathrm{t}_{0,05: 6}=2,179$ sehingga menerima $\mathrm{H}_{\mathrm{o}}$ dan menolak $\mathrm{H}_{\mathrm{a}}$ dimana hal ini menjelaskan bahwa posisi pintu masuk (entrance) bubu apung tidak berpengaruh terhadap hasil tangkapan pada tingkat kepercayaan $95 \%$.
Penentuan posisi pintu masuk (entrance) bagian depan, belakang, samping kiri dan kanan didasarkan pada posisi tali pemberat pada rumpon. Bila tali pemberat berputar mengikuti arus maka pintu masuk (entrance) bubu bagian depan yang berhadapan langsung dengan tali pemberat akan berputar mengikuti perputaran tali pemberat. Keadaan ini memberi peluang sebesar-besarnya pada objek tangkapan untuk masuk ke dalam pintu masuk (entrance) bubu bagian depan/belakang dan samping kiri/kanan.

Tabel 3. Analisis uji t untuk jumlah tangkapan ikan

\begin{tabular}{ccccc}
\hline \multicolumn{5}{c}{ Jumlah hasil tangkapan (ekor) } \\
\hline \multirow{2}{*}{ Trip Operasi } & $\begin{array}{c}\text { Pintu Depan Dan } \\
\text { Belakang }\left(\mathrm{X}_{1}\right)\end{array}$ & $\begin{array}{c}\text { Pintu Samping Kanan Dan } \\
\text { Samping Kiri }\left(\mathrm{X}_{2}\right)\end{array}$ & $\mathrm{X}_{1}{ }^{2}$ & $\mathrm{X}_{2}{ }^{2}$ \\
\hline 1 & 8 & 9 & 64 & 81 \\
2 & 5 & 4 & 25 & 16 \\
3 & 4 & 5 & 16 & 25 \\
4 & 10 & 4 & 100 & 16 \\
5 & 22 & 4 & 484 & 16 \\
6 & 89 & 79 & 7921 & 6241 \\
7 & 269 & 190 & 72361 & 36100 \\
Total & $\Sigma \mathrm{X}_{1}=407$ & $\Sigma \mathrm{X}_{2}=295$ & $\Sigma \mathrm{X}_{1}^{2}=80971$ & $\Sigma \mathrm{X}_{2}{ }^{2}=42495$ \\
\hline
\end{tabular}


Diterimanya hipotesis Ho dalam penelitian ini yaitu tidak berpengaruhnya posisi pintu masuk (entrance) bubu, dalam hal ini Pintu masuk (entrance) bagian depan/belakang dan samping kanan/kiri terhadap hasil tangkapan ikan, diduga disebabkan karena kondisi oseanografis khususnya arus sebagai penentu posisi pintu masuk (entrance) dimana pada saat penelitian kondisinya tidak menentu terkadang berarus tetapi terkadang juga tidak berarus.

Pada trip penangkapan ke 1-5 hasil tangkapan yang diperoleh masih sedikit tidak sebanding dengan hasil tangkapan trip 6 dan 7. Pada trip ke 15 tertangkap ikan Abudefduf vaigiensis dari famili Phomachatidae dan ikan Aluterus scriptus dari famili Monachntiae. Menurut Setiapermana (1996) bahwa famili Phomachatidae dan famili Monachntiae adalah ikan diurnal atau aktif mencari makan pada siang hari yang menyerupai periode aktif mencari makan ikan layang dan ikan selar, yaitu pada waktu diantara kedua waktu malam dan siang hari. Kemungkinan tertangkapnya kedua jenis ikan karang ini karena periode aktif mencari makan pada siang hari yang bersamaan dengan periode aktif ikan pelagis mencari makan. Sedangkan penggunaan lampu di rumpon memanfaatkan tingkah laku ikan pelagis yang mencari makan pada malam hari dan tertangkap.

Pada trip penangkapan ke 3 setelah alat diangkat dari perairan, alat tersebut mengalami kerusakan (rangka besi patah) diduga akibat oleh serangan ikan predator atau pemangsa yang menabrak bubu sehingga perlu dilakukan perbaikan pada alat tersebut.

Pada trip penangkapan ke 6 dan ke 7 diperoleh ikan pelagis yang merupakan objek tangkapan, yaitu ikan layang (Decapterus sp) dan ikan selar (Selaroides sp). Keberadaan ikan pelagis pada kedua trip ini menunjukkan bahwa alat tersebut memerlukan waktu yang cukup lama untuk berasosiasi pada lingkungan perairan sekitar agar ikan pelagis tertangkap. Walaupun alat ini mengalami masa perendaman selama 3 hari setiap trip penangkapan dan dinding bubu sudah ditutupi dengan daun kelapa (Cocos rucifera) yang merupakan atraktor untuk menggiring ikan masuk ke dalam bubu (LLifle Encyclopedian of living forms, 2018). Tertangkapnya ikan pelagis ini dipengaruhi oleh musim penangkapan, tingkah laku ikan baik secara individu maupun alamiah Gunarso (1985).
Pada penelitian ini dilakukan 7 trip operasi, pada kenyataanya belum mendapat hasil maksimal sebab pengoperasian alat tangkap bubu apung diperlukan waktu sekitar 6 bulan, untuk mengetahui keberhasilan dari alat tangkap bubu dan pintu bagian mana yang memberikan hasil tangkapan ikan target paling maksimal (Paransa dan Pamikiran, 2018). Sedangkan operasi penangkapan dalam penelitian hanya berjalan 21 hari jumlah tangkapan yang didapat ikan Decapterus sp 378 ekor dan ikan Selaroides sp 252 ekor, kemungkinan dengan tambahan trip tersebut akan menambah hasil tangkapan ikan target.

Posisi pintu masuk (entrance) bubu langsung terdapat pada dinding bubu kemungkinan menyebabkan ikan objek tangkapan tertangkap, karena menganggap bubu apung sebagai tempat berlindung dari pengejaran predator (predasi). Posisi pintu masuk (entrance) bubu, sebaiknya diletakkan ke arah dalam, posisi ini akan menggiring ikan masuk dalam bubu dan ikan tertangkap. Pintu masuk (entrance) bubu apung yang terdapat pada dinding bubu apung dipasang tidak mencorong ke arah dalam tetapi dipasang langsung pada dinding bubu, yang merupakan salah satu faktor penunjang dari keberhasilan alat tangkap ini.

Bubu apung berbentuk empat persegi panjang dengan ukuran $2 \times 1 \mathrm{~m}$ dapat pula mengurangi efiensi penangkapan karena ukuran ini cukup besar dan berat pada saat pelepasan alat yang harus dilakukan di bawah rumpon dan pada saat penangkutan di atas perahu menuju ke daerah penangkapan juga pada saat pengangkatan alat..

\section{KESIMPULAN}

1. Keberhasilan tangkapan ikan dengan bubu apung dipengaruhi oleh konstruksi Pintu masuk (entrance) bubu dan tingkah laku ikan pelagis.

2. Posisi Pintu masuk (entrance) tidak berpengaruh diduga disebabkan karena kondisi oseanografis khususnya arus yang merupakan penentu dari posisi Pintu masuk (entrance), kondisinya tidak menentu terkadang berarus tetapi terkadang juga tidak berarus.

3. Hasil tangkapan adalah ikan pelagis dan ikan indikator antara lain ikan Decapterus sp.; ikan Selaroides sp. dan ikan Abudefduf vaigiensis, ikan Aluterus scriptus. 


\section{DAFTAR PUSTAKA}

Allen, G. 2000. Marine Fishes of South East Asia. Periplus Edition Ltd.

Dimara F.O, Budiman, J., Mandey C.F.T. 2015. Distribusi Tertangkapnya Ikan Selar Pada Lembaran Jaring Soma Darape. Jurnal Ilmu dan Teknologi Perikanan Tangkap. Universitas Sam Ratulangi. Manado

Gunarso, W. 1985. Tingkah Laku Ikan Dalam Hubungannya Dengan Alat, Metoda Dan Taktik Penangkapan. Diktat kuliah. Institut Pertanian Bogor. 149 hal.

Hasan, I. 2004. Analisis Data Penelitian Dengan Statistik. PT. Bumi Aksara. Jakarta. 220 hal.

LLifle Encyclopedias of Living Forms. 2018. The Encyclopedia of Palms and Cycads [7/7/2018]

Mandagi, C., Kalangi P.N.I, Luasunaung, A. 2016. Luas Cakupan Perpindahan Rumpon Di Teluk Manado. Jurnal
Ilmu dan Teknologi Perikanan Tangkap. Universitas Sam Ratulangi. Manado. 2(3).105-108.

Paransa, I.J, Pamikiran R.D.CH. 2018. Inilah Bubu Apung Perangkap Ikan Tanpa Merusak Karang. Mongabay Web Tentang Lingkungan. dari Mongabay.co.id

Setiapermana, D. 1996. Potensi Wisata Bahari Pulau Mapor. P30-LIPI, Jakarta

Kementerian Kelautan Dan Perikanan Republik Indonesia (KKP). 2017. Maritim Indonesia, Kemewahan Yang Luar Biasa. Artikel Kantor Kesehatan Pelabuhan Indonesia [Https://kkp.go.id/artikel/2233-maritim-indonesiakemewahan-yang-luar-biasa [20/11/2017]

Peraturan Menteri Kelautan dan Perikanan Republik Indonesia (PERMEN KP).2016. Nomor 23 Tentang Perencanaan Pengelolaan Wilayah Pesisir dan Pulau kecil 